\title{
Geolocation dengan Metode Djikstra untuk Menentukan Jalur Terpendek Lokasi Peribadatan
}

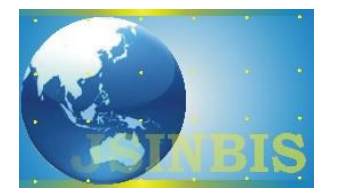

\author{
Noor Azizah ${ }^{\mathrm{a}^{*}}$, Danang Mahendra ${ }^{\mathrm{a}}$ \\ ${ }^{a}$ Universitas Islam Nahdlatul Ulama Jepara
}

Naskah Diterima : 12 September 2017; Diterima Publikasi : 23 Oktober 2017

DOI : 10.21456/vol7iss2pp96-103

\begin{abstract}
Traveling from one place to another takes time and cost. Especially for tourists who get difficulties to find worship locations because of a vast area with the numbers of worship location. This study aims to design application based android to determine the location of worship with the shortest path. A method used to develop the application is Waterfall method that includes the beginning of the analysis phase up to the application maintenance stage. Result from this research is Djikstra method can searching the location with the shortest path. Geolocation technology is used to identify a real-world geographical location that can be applied to the android operating system. As a case study, this research has been successfully applied to searching the location of worship in Kudus District include mosques, christian churches, catholic churches, and monasteries.
\end{abstract}

Keywords : Geolocation; Djikstra Method; Android

\begin{abstract}
Abstrak
Perjalanan dari suatu tempat ke tempat yang lain membutuhkan waktu dan biaya. Terlebih bagi para wisatawan yang kesulitan untuk mencari lokasi peribadatan dikarenakan wilayah yang sangat luas dan dengan jumlah lokasi peribadatan yang banyak. Penelitian ini bertujuan untuk membangun aplikasi berbasis android untuk menentukan lokasi peribadatan dengan jalur terpendek. Metode yang digunakan untuk pengembangan aplikasi tersebut adalah dengan menggunakan metode waterfall yang mencakup mulai tahap analisis sampai dengan tahap perawatan aplikasi. Hasil dari penelitian ini menunjukkan bahwa metode djikstra dapat digunakan untuk mencari lokasi dengan jalur terpendek. Teknologi geolocation digunakan untuk mengidentifikasi sebuah lokasi geografis pada dunia nyata yang dapat di aplikasikan pada sistem operasi android. Sebagai studi kasus, penelitian ini telah berhasil diterapkan pada pencarian lokasi peribadatan di Kabupaten Kudus meliputi masjid, gereja kristen, gereja katolik, dan vihara.
\end{abstract}

Kata kunci: Geolocation; Metode djikstra; Android

\section{Pendahuluan}

Fasilitas umum yang sering diakses maupun digunakan salah satunya adalah tempat peribadatan yang merupkan kebutuhan dasar umat manusia. Informasi mengenai keberadaan tempat peribadatan ini dinilai sangat diperlukan terutama untuk masjid yang mayoritas masyarakat di Indonesia adalah muslim.

APJII (Asosiasi Penyelenggara Jasa Internet Indonesia) (2016), pengguna internet di Indonesia sejumlah 132,7 juta penduduk. Adapun data pengguna internet sebagaimana Tabel 1 .

Akses internet melalui mobile saat ini menjadi pilihan utama dibandingkan dengan personal computer (PC) atau laptop. APJII (2016), Pengguna internet di Indonesia mengakses melalui komputer sekitar $1,7 \%$, mengakses melalui mobile sejumlah $47,6 \%$, sedangkan $50,7 \%$ lainnya mengakses melalui komputer dan mobile. Hal tersebut memicu banyak aplikasi yang kemudian dikembangkan atau dimigrasikan menjadi berbasis telepon selular (mobile). Hal ini merupakan peluang yang sangat besar bagi pengembang aplikasi mobile untuk membuat aplikasi-aplikasi yang sesuai dengan kebutuhan pengguna mobile saat ini. Android merupakan software berbasis komputer yang bisa didistribusikan secara terbuka (open source) sehingga programmer dapat membuat aplikasi baru di dalamnya.

*) Noor Azizah : azizah@unisnu.ac.id 
Tabel 1. Data pengguna internet di indonesia

\begin{tabular}{clcl}
\hline No & \multicolumn{1}{c}{ Daerah } & Jumlah & Persentase \\
\hline 1 & Sumatera & 20.752 .185 & $15,7 \%$ \\
2 & Jawa & 86.339 .350 & $65 \%$ \\
3 & Bali dan Nusa & 6.148 .796 & $4,7 \%$ \\
4 & Kalimantan & 7.685 .992 & $5,8 \%$ \\
5 & Sulawesi & 8.454 .592 & $6,3 \%$ \\
6 & Maluku dan & 3.330 .596 & $2,5 \%$ \\
& Papua & & \\
\hline
\end{tabular}

Sumber : APJII, 2016

Yulianto (2010), Perpaduan antara posisi dan rute terpendek ini akan menjadi suatu aplikasi yang berguna dalam memenuhi kebutuhan akan informasi lokasi (tempat) bagi masyarakat, khususnya bagi merekayang banyak melakukan pekerjaan atau aktivitas dan menghabiskan waktu di luar bangunan. Perangkat pencarian tersebut menyediakan data dalam bentuk visual (grafik) yang dapat diakses secaracepat dan murah.

Fajaruddin dan Tarmuji (2013) Salah satu fitur yang ada pada perangkat mobile adalah layanan internet yang dilengkapi dengan fitur GPS (Global Positioning System). Dengan adanya fitur GPS ini, para pengguna android dapat mencari lokasi tertentu dari posisi pengguna dengan lebih nyaman dan dapat di akses menggunakan smartphone. Dalam perjalanan dari satu tempat ke tempat yang lain, orang mempertimbangkan efisiensi waktu dan biaya. Oleh karena itu, sebuah aplikasi berbasis mobile sangat diperlukan untuk pencarian sebuah lokasi tempat peribadatan.

Gusmão and Pramono (2013) Geolocation merupakan proses mendeteksi lokasi keberadaan kita menggunakan koneksi internet. Dengan geolocation kita juga dapat menampilkan pencarian rute sebagai informasi yang penting bagi pengguna dalam melakukan perjalanan.

Pratiarso dkk. (2010) Salah satu metode yang digunakan sebagai solusi pencarian rute terpendek adalah algoritma Dijkstra. Algoritma ini tepat dan mudah diimplementasikan untuk pencarian jalur terpendek. Selain itu, algoritma Dijkstra juga lebih intensif dalam komputasi untuk pencarian jalur optimum dalam suatu jaringan seperti internet, dan waktu rata-rata eksekusi algoritma Dijkstra lebih kecil dibanding algoritma Ant Colony, maka algoritma Dijkstra banyak digunakan dalam pencarian jalur optimum pada jaringan internet dibanding algoritma lain.

Berdasarkan beberapa penelitian terdahulu, maka akan dikembangkan sebuah rekayasa teknologi geolocation untuk pencarian lokasi peribadatan dengan jalur terpendek menggunakan metode djikstra yang akan diimplementasikan dalam perangkat smartphone.

Penelitian ini bertujuan untuk membangun aplikasi berbasis android untuk menentukan lokasi peribadatan dengan jalur terpendek dengan metode metode djikstra untuk menentukan jalur terpendek dari sebuah lokasi. Implementasi teknologi geolocation dalam sistem ini digunakan sebagai alat untuk menentukan lokasi berbasis mobile.

\section{Kerangka Teori}

\subsection{Geolocation}

Anwar dkk. (2015) Geolocation adalah identifikasi lokasi geografis suatu objek pada dunia nyata. Geolocation mempunyai kaitan erat dengan positioning, perbedaannya adalah geolocation lebih spesifik dalam menentukan sebuah lokasi (misalnya alamat jalan) dibandingkan dengan positioning yang hanya mencakup sekumpulan koordinat geografis. Suatu lokasi geografis mengandung nilai latitude dan longitude.

Adapun konsep dari geolocation seperti pada gambar 1:

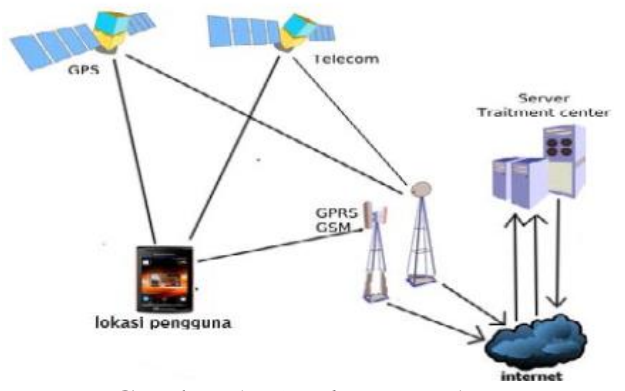

Gambar 1. Geolocation API

Konsep dasar geolocation adalah ISP (internet service provider) atau GSM berfungsi untuk memacarkan sinyal koneksi internet yang terhubung dengan satelit GPS dan telecom. Semua data yang ada, akan disimpan pada server. Selanjutnya pengguna mengakses pencarian lokasi melalui smartphone yang sudah terhubung dengan GPS tersebutu. GPS ini berfungsi untuk menentukan titik longitude dan latitude sebuah lokasi yang dicari.

\subsection{Algoritma Djikstra}

Roqib dkk. (2014), Algoritma Djikstra ditemukan oleh Edsger Wybe Djikstra pada tahun 1959. Algoritma djikstra merupakan algoritma yang sering digunakan dalam pecarian rute terpendek. Dalam mencari solusi, Algoritma Djikstra mengunakan prinsip greedy, yaitu mencari solusi optimum pada setiap langkah yang dilewati, dengan tujuan untuk memperoleh solusi terbaik pada langkah selanjutnya yang akan mengarah pada solusi optimum.

Munir (2005), Algoritma ini bertujuan untuk menemukan jalur terpendek berdasarkan bobot terpendek berdasarkan bobot terkecil dari satu titik ke titik lainya. 


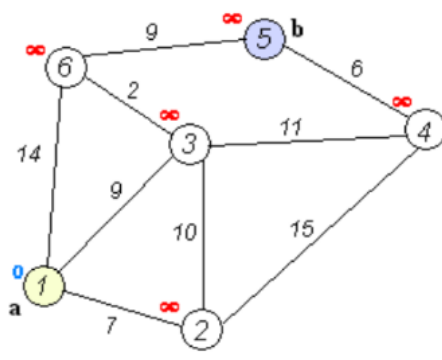

Gambar 2. Keterhubungan antar titik pada Djikstra

Langkah pertama tentukan mana yang akan menjadi node awal, lalu beri bobot jarak pada node pertama ke node terdekat satu per satu, Djikstra akan melakukan pengembangan pencarian dari satu titik ke titik lain dan ketitik selanjutnya tahap demi tahap. Adapun langkah-langkah kerja metode djikstra adalah sebagai berikut :

a. Beri nilai bobot (jarak) untuk setiap titik lainya, lalu set nilai 0 pada node awal dan nilai tak hingga terhadap node lain.

b. Set semua node "belum terjamah" dan set node awal sebagai node keberangkatan.

c. Dari node keberangkatan petimbangkan node tetangga yang belum terjamah dan hitung jaraknya dari titik keberangkatan sebagai contoh jika titik keberangkatan A ke B memiliki bobot 6 dan dari B ke node $\mathrm{C}$ berjarak 2, maka jarak ke $\mathrm{C}$ melewati $\mathrm{B}$ menjdai $6+2=8$. Jika jarak ni lebih kecil dari jarak sebelumnya hapus data lama, simpan ulang data jarak dengan jarak yang baru.

d. Saat kita selesai mempertimbangkan setiap jarak terhadap node tetangga, tandai node yang terjamah sebagai node terjamah. Node terjamah tidak akan pernah di cek kembali, jarak yang disimpan adalah jarak terakhir dan yang minimal.

e. Set node belum terjemah dengan jarak terkecil sebagai node keberangkatan selanjutnya dengan kembalike step 3 .

Adapun prosedur pseudocede metode djikstra adalah sebagai berikut :

a. Pseudocode kode sumber (user)

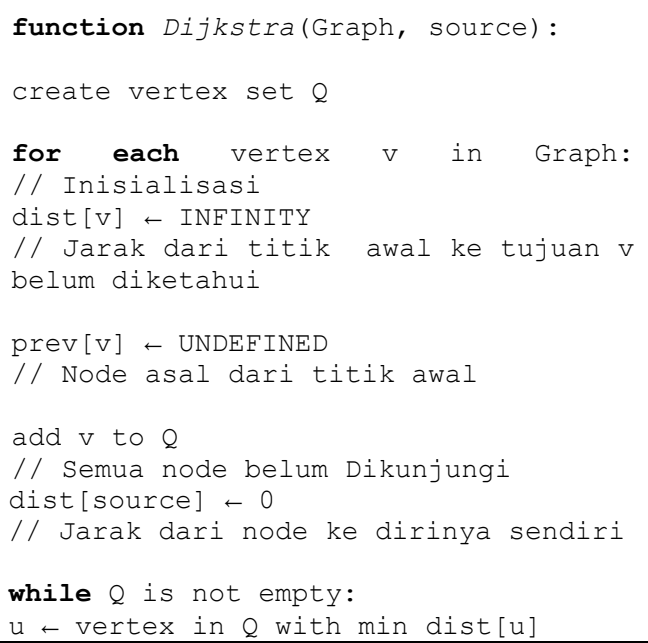

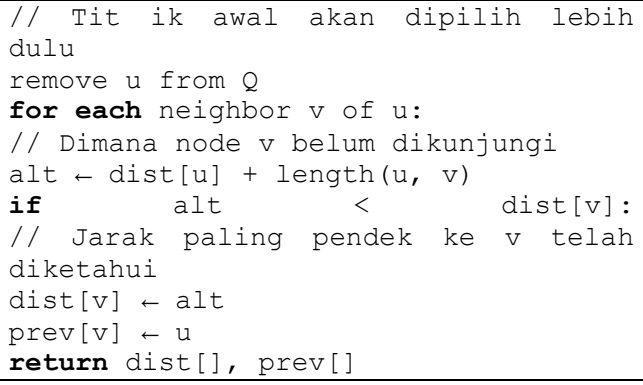

b. Pseudocode Jalur Terpendek

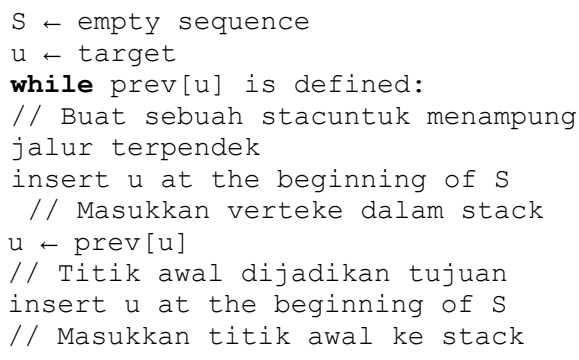

Pengujian dilakukan untuk mendapatkan kesesuaian jarak dari titik awal sampai titik akhir pada peta yang dihasilkan oleh algoritma Dijkstra dengan jarak pengukuran. Untuk mendapatkan seberapa besar persen selisih nilai antara jarak pengukuran dengan jarak yang hasil Dijkstra dapat dihitung dengan persamaan (1).

$S_{j}=\left[\frac{\sum_{i=1}^{N}\left(P_{1}-P_{2}\right)}{N}\right] \times 100 \%$

Dimana :

$S_{j} \quad=$ selisih jarak (nilai rata-rata)

$P_{1} \quad=$ Jarak pengukuran

$P_{2} \quad=$ Jarak yang dihasilkan Djikstra

\section{Metode}

\subsection{Metode Pengumpulan Data}

Penelitian tentang pencarian lokasi peribadatan dilakukan di Kabupaten Kudus mengambil data dari Kantor Kementerian Agama Kabupaten Kudus yang beralamatkan di Jl. Mejobo No.27, Mlati Lor, Kota Kabupaten Kudus. Adapun data yang kami peroleh berupa data masjid, gereja kristen, gereja katolik, dan vihara sejumlah 661 data yang tersebar di sembilan kecamatan di Kabupaten Kudus. Data yang berasal dari Kantor Kementerian Agama Kabupaten Kudus hanya berupa nama, lokasi atau alamat, dan deskripsi tempat peribadatan saja. Adapun lokasi tepat dari tempat peribadatan berdasarkan titik longitude dan latitude, peneliti observasi langsung ke lokasi tempat peribadatan untuk menentukan titik yang paling tepat sebagai bahan untuk perhitungan jalur terpendek menggunakan metode djikstra yang akan diimplementasikan ke aplikasi. 


\subsection{Prosedur Penelitian}

Tahapan dalam penelitian ini, penulis menggunakan pendekatan model waterfall. Model Waterfall merupakan model yang paling populer dan sering dianggap sebagai pendekatan klasik dalam daur hidup pengembangan sistem. Pada metode waterfall terdapat 6 tahapan seperti yang digambarkan pada Gambar 4., yaitu : analysis, requirements specification, design, implementation, testing and integration, operation and maintenance.

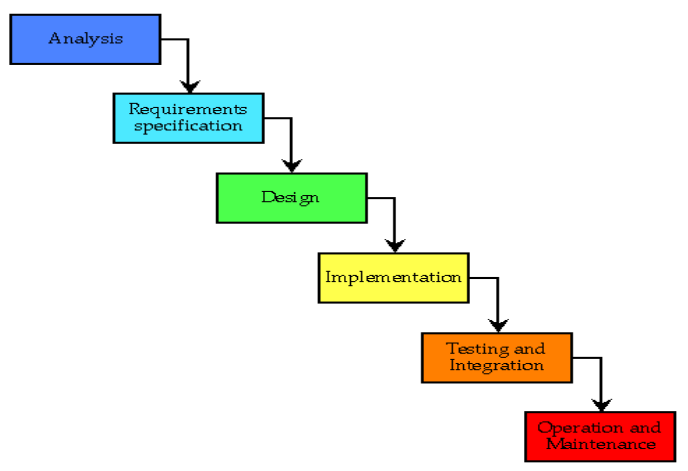

Gambar 3. Prosedur Penelitian

Tahapan pengembangan sistem yang akan dibangun meliputi beberapa tahapan antara lain :

a. Analisis masalah dan analisa spesifikasi kebutuhan

Pada tahap ini dilakukan analisa terhadap objek penelitian. Kegiatan yang dilakukan adalah :

1) Analisis kebutuhan data dan informasi

Yaitu menganalisis data apa saja yang diperlukan dan informasi apa saja yang akan dihasilkan dari pengolahan data yang ada. Selain itu juga menganalisis kebutuhan software yang digunakan untuk membuat permodelan serta membangun sistem.

2) Analisis kebutuhan sistem

Yaitu menganalisis dalam rangka pembangunan aplikasi pencarian lokasi dengan jalur terpendek dengan memanfaatkan geolocation, adapun kegiatan ang dilakukan pada tahap ini adalah :

b. Mengidentifikasi masalah yang ada pada proses pencarian lokasi tempat peribadatan

c. Mengidentifikasi kebutuhan teknologi informasi untuk pencarian sebuah lokasi denganjalur terpendek

d. Memberikan alternatif teknologi dalam hal pencarian sebuah lokasi dengan jalur terpendek, pada bagian ini berisi segala kebutuhan yang diperlukan baik software, hardware dan sumber daya manusia.

b. Perancangan

Perancangan sistem merupakan tahapan inti dari sebuah rancang bangun sebuah proses. Pada tahap ini dilakukan penyusunan rancang bangun aplikasi geolocation menggunakan metode djikstra untuk menentukan jalur terpendek. Perancangan sistem ini, berfokus pada bagaimana merancang sebuah struktur data di dalam sistem, arsitektur perangkat lunak, representasi interface, dan detail (algoritma) prosedural. Rancangan arsitektur sistem seperti pada Gambar 5.

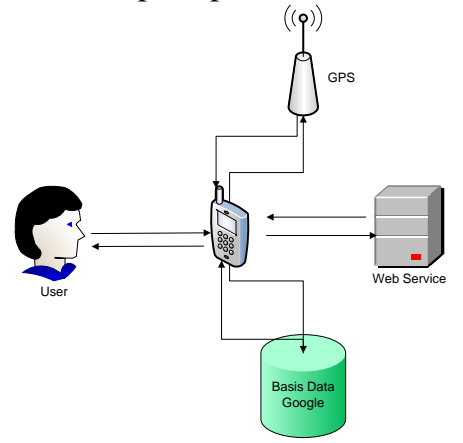

Gambar 4. Rancangan Arsitektur Sistem

Sistem yang dibangun nantinya akan di implementasikan pada perangkat android. Dimana android tersebut akan terhubung dengan GPS. Sedangkan semua data tentang lokasi peribadatan akan disimpan pada server.

Braun et al. (2001) Dalam penelitian ini perancangan menggunakan Unified Modelling Language (UML) adalah suatu alat untuk memvisualisasikan dan mendokumentasikan hasil analisa dan desain yang berisi sintak dalam memodelkan system secara visual.

Dalam perancangan ini akan di gunakan Usecase Diagram dan Class Diagram.

a. Usecase Diagram

Usecase diagram berfungsi untuk menggambarkan fungsional dari sistem informasi geolocation yang akan di buat. Dalam usecase ini nanti akan ada dua actor yaitu admin dan user.
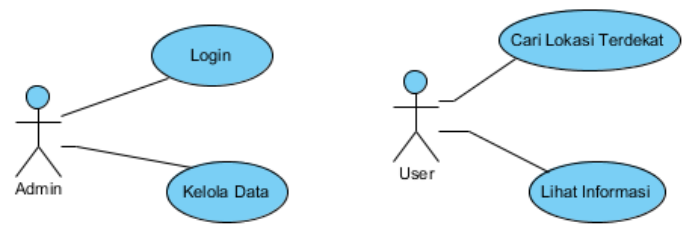

Gambar 5. Usecase Diagram

Dalam usecase diagram diatas nanti aktor admin akan login terlebih dahulu sebelum bisa kelola data yaitu menginput data tempat ibadah, mengedit data tempat ibadah dan menghapus data tempat ibadah. Aktor user akan memilih cari lokasi jarak terpendek tempat ibadah dan lihat informasi tempat ibadah. 


\section{b. Class Diagram}

Class Diagram merupakan gambaran dari database yang akan digunakan oleh sisem geolocation ini.

\begin{tabular}{|l|}
\hline \multicolumn{1}{|c|}{ Admin } \\
\hline -Username \\
-Password \\
\hline +Login() \\
\hline
\end{tabular}

\begin{tabular}{|l|}
\hline \multicolumn{1}{|c|}{ Tempat_Ibadah } \\
\hline -Id_Tempat \\
-Nama_Tempat \\
-Kategori \\
-Alamat \\
-Gambar \\
-Latitude \\
-Longitude \\
\hline +Simpan() \\
+Edit() \\
+Hapus() \\
\hline
\end{tabular}

Gambar 6. Class Diagram GIS

Class diagram diatas mempunyai dua class yaitu class admin dan class tempat ibadah. Class admin mempunyai atribut username dan password dan mempunyai operasi login, sedangkan class tempat ibadah mempunyai attribute id tempat, nama tempat, kategori, alamat, gambar, latitude dan longitude serta memiliki operasi simpan, edit, dan hapus.

c. Implementasi

Merupakan taapan yang dilakukan untuk menyelesaikan desain sistem yang sudah dirancang. Dalam hal ini dilakukan pembuatan aplikasi geolocation menggunakan metode djikstra yan akan diimplementasikan pada perangkat android. Aplikasi akan di buat menggunakan Android Studio, untuk peta maps akanmenggunakan library Maps API. Untk halaman admin akan enggunakan bahasa pemrograman PHP.

d. Pengujian

Setelah aplikasi selesai dibangun, maka tahapan berikutnya adalah menguji aplikasi tersebut dengan cara menguji cobakan pada beberapa sample user untuk memastikan bahwa sistem yang kita bangun tidak ada permasalahan. Setelah aplikasi selesai di bangun, maka tahapan berikutnya adalah pengujian. Pengujian menggunakan pengujian blackbox yang bertujuan untk melihat validatas fungsional sistem.

e. Perawatan

Perawatan terhadap sistem juga dilakukan setelah aplikasi tersebut dapat dijalankan. Tujuannya adalah agar aplikasi geolocation tersebut selalu up to date terhadap pertambahan data.

\section{Hasil dan Pembahasan}

\subsection{Aplikasi Geolocation}

Penelitian ini menghasilkan sebuah aplikasi pencarian lokasi tempat peribadatan dengan jalur terpendek berbasis android. Pada aplikasi ini, ada dua halaman yang dibuat yaitu halaman user yang merupakan interface bagi pengguna untuk mencari lokasi tempat peribadatan. Selain itu, ada halaman admin yang berfungsi untuk memasukkan data lokasi tempat peribadatan serta merubah data jika ada data kurang tepat.

Pada halaman user, terdapat pilihan menu untuk memilih jenis tempat peribadatan apa yang dipilih meliputi masjid, gereja kristen, gereja katolik, dan vihara. Hal tersebut tergambarkan seperti pada Gambar 6.

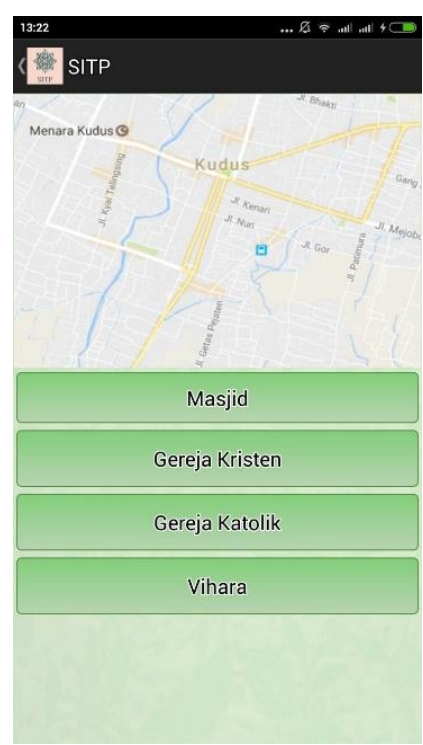

Gambar 6. Halaman user untuk memilih jenis tempat peribadatan

Selanjutnya, ketika user sudah memilih jenis tempat peribadatannya, secara otomatis sistem akan menampilkan lokasi tempat peribadatan terdekat dari posisi user berdiri melalui pengimplementasian metode djikstra. User dapat memilih dengan sendiri tempat peribadatan mana yang akan dikunjungi dengan cara klik gambar salah satu tempat peribadatan. Di menu sudah ada foto, nama tempat peribadatan dan jarak antara user dengan lokasi tujuan. Tampilan aplikasi seperti pada Gambar 7.

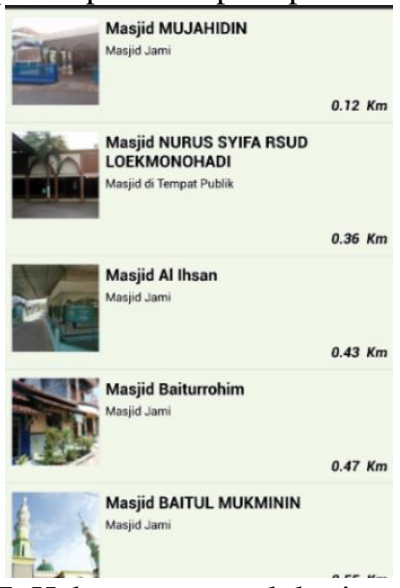

Gambar 7. Halaman tempat lokasi peribadatan terdekat

Halaman selanjutnya setelah user memilih lokasi peribadatan yang akan di kunjungi maka akan 
muncul profil masjid yang berisi nama masjid, Lokasi, jarak dari user dan deskripsi masjid. Halaman profil tempat peribadatan seperti pada Gambar 8.

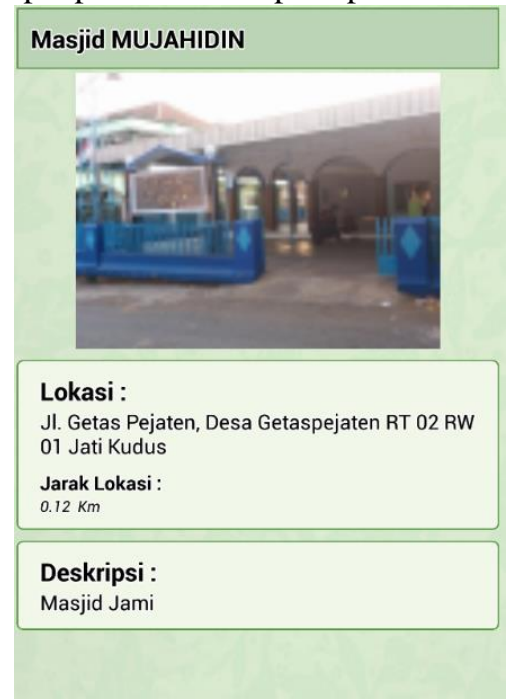

Gambar 8. Halaman profil tempat peribadatan

Setelah itu, halaman yang ditampilkan adalah jalur menuju tempat peribadatan yang di pilih oleh user seperti pada Gambar 9. Gambar tersebut menampilkan dua titik. Titik pertama menampilkan tempat berdiri user dan titik kedua menampilkan tujuan user. Sistem ini terintegrasi dengan Google Maps menggunakan Map API, maka jalur yang akan dilalui user secara otomatis merupakan rute terpendek.

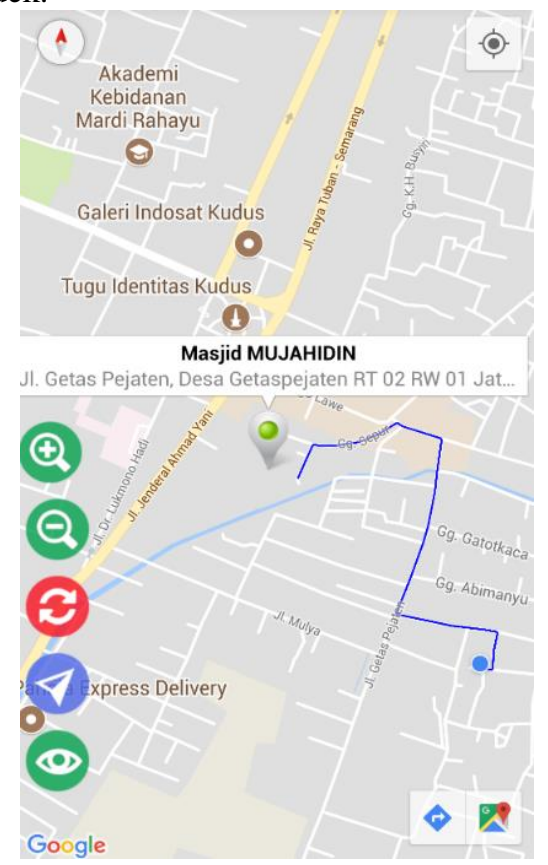

Gambar 9. Halaman jalur menuju tempat peribadatan

Halaman admin merupakan halaman untuk mengelola aplikasi yang meliputi input data, update data, dan delete data. Pada halaman utama admin, akan ditampilkan semua menu yang bisa dikelola oleh admin seperti pada Gambar 10.

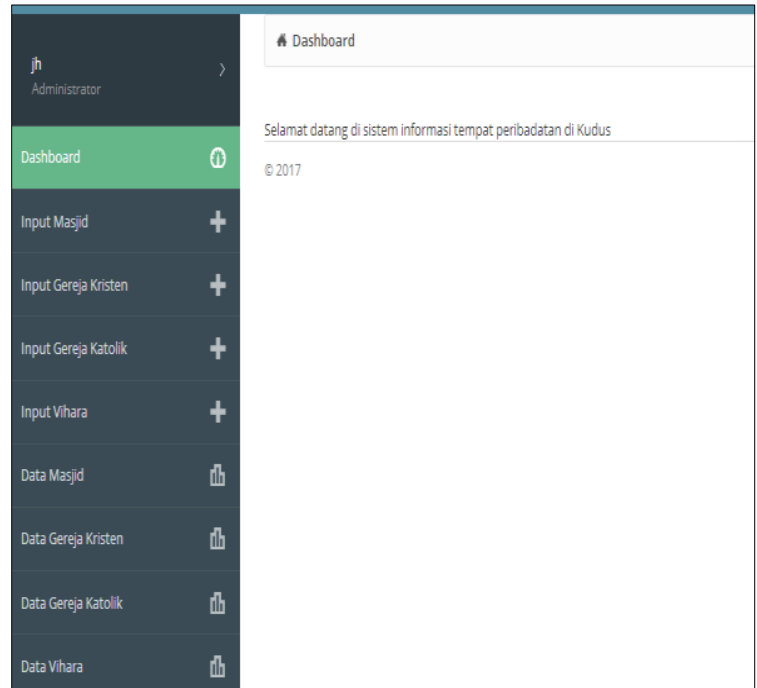

Gambar 10. Halaman utama admin

Pada halaman utama admin, ada dua menu utama yaitu halaman input data dan halaman detail informasi mengenai tempat peribadatan. Pada halaman input, seorang admin dapat memasukkan data berupa nomor id, nama, alamat, keterangan, gambar tempat peribadatan, serta data lokasi berdasarkan titik longitude dan latitude.

\subsection{Implementasi Algoritma Djikstra}

Perhitungan jarak pada sistem yang menghasilkan output berupa rekomendasi lokasi peribadatan terdekat menggunakan algoritma djikstra yang dimasukkan dalam coding syntax. Pada pengujian sistem pencarian lokasi dengan jalur terpendek, peneliti hanya menggunakan variabel jarak. Jarak diambil dari posisi user saat ini dan titik ahir tujuan. Adapun hasil pengujian dengan sampel titik awal 3 lokasi untuk pencarian lokasi peribadatan jenis masjid, tergambarkan pada Tabel 2.

Tabel 2. Data pengujian rute terpendek

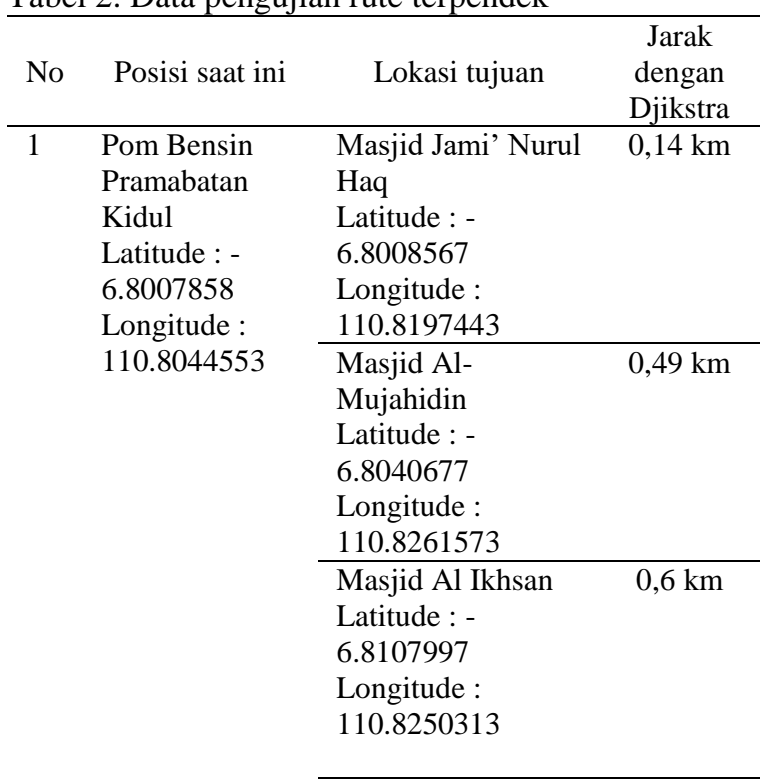




\begin{tabular}{|c|c|c|c|}
\hline No & Posisi saat ini & Lokasi tujuan & $\begin{array}{c}\text { Jarak } \\
\text { dengan } \\
\text { Djikstra }\end{array}$ \\
\hline \multirow[t]{3}{*}{2} & \multirow[t]{3}{*}{$\begin{array}{l}\text { Museum } \\
\text { Kretek Kudus } \\
\text { Latitude : - } \\
6.8263837 \\
\text { Longitude : } \\
110.8355499\end{array}$} & $\begin{array}{l}\text { Masjid Al fatah } \\
\text { Latitude : - } \\
6.8234407 \\
\text { Longitude : } \\
110.8368163\end{array}$ & $0,24 \mathrm{~km}$ \\
\hline & & $\begin{array}{l}\text { Masjid } \\
\text { Baiturochim } \\
\text { Latitude : - } \\
6.8263252 \\
\text { Longitude : } \\
110.8368052\end{array}$ & $0,45 \mathrm{~km}$ \\
\hline & & $\begin{array}{l}\text { Masjid Jami Nur } \\
\text { Muthna'innah } \\
\text { Latitude : - } \\
6.8287221 \\
\text { Longitude : } \\
110.8366273\end{array}$ & $0,75 \mathrm{~km}$ \\
\hline \multirow[t]{3}{*}{3} & \multirow[t]{3}{*}{$\begin{array}{l}\text { Alun-Alun } \\
\text { Simpang } 7 \\
\text { Kudus } \\
\text { Latitude : - } \\
6.8078469 \\
\text { Longitude : } \\
110.8395113\end{array}$} & $\begin{array}{l}\text { Masjid Agung } \\
\text { Kudus } \\
\text { Latitude : - } \\
6.807773 \\
\text { Longitude : } \\
110.8395738 \\
\end{array}$ & $0,1 \mathrm{~km}$ \\
\hline & & $\begin{array}{l}\text { Masjid Al Ittihad } \\
\text { Latitude : - } \\
6.8068497 \\
\text { Longitude : } \\
110.8422733\end{array}$ & $0,3 \mathrm{~km}$ \\
\hline & & $\begin{array}{l}\text { Masjid Al Falah } \\
\text { Latitude : - } \\
6.8013467 \\
\text { Longitude : } \\
110.8419443\end{array}$ & $0,65 \mathrm{~km}$ \\
\hline
\end{tabular}

\subsection{Pengujian Sistem}

Pelaksanaan pengujian di lakukan dengan metode blackbox yang berfokus pada fungsional dari perangkat lunak. (Sidi, 2015), Tester dapat mendefinisikan kumpulan kondisi input dan melakukan pengetesan pada spesifikasi fungsional program.

Terdapat empat tabel uji yaitu login admin, kelola data, cari lokasi terdekat, dan lihat informasi.

Tabel 3. Hasil uji login admin

\begin{tabular}{|c|c|c|c|}
\hline No & Deskripsi & $\begin{array}{c}\text { Prosedur } \\
\text { Pengujian }\end{array}$ & Hasil \\
\hline 1 & $\begin{array}{l}\text { Pengujian } \\
\text { Login }\end{array}$ & $\begin{array}{l}\text { Memasukkan } \\
\text { username dan } \\
\text { pasword untuk } \\
\text { masuk } \\
\text { kehalaman } \\
\text { Admin }\end{array}$ & Diterima \\
\hline 2 & $\begin{array}{l}\text { Pengujian login } \\
\text { dengan } \\
\text { username dan } \\
\text { password yang } \\
\text { tidak ada di } \\
\text { sistem }\end{array}$ & $\begin{array}{l}\text { Memasukkan } \\
\text { username dan } \\
\text { password yang } \\
\text { tidak ada pada } \\
\text { sistem }\end{array}$ & Diterima \\
\hline
\end{tabular}

Tabel 4. Hasil uji kelola data

\begin{tabular}{cccc}
\hline $\begin{array}{c}\mathrm{N} \\
\mathrm{O}\end{array}$ & \multicolumn{1}{c}{ Deskripsi } & \multicolumn{1}{c}{$\begin{array}{c}\text { Prosedur } \\
\text { Pengujian }\end{array}$} & Hasil \\
\hline 1 & $\begin{array}{l}\text { Pengujian } \\
\text { tambah data }\end{array}$ & $\begin{array}{l}\text { Mengisi data } \\
\text { dan Menyimpan } \\
\text { data }\end{array}$ & Diterima \\
2 & $\begin{array}{l}\text { Pengujian edit } \\
\text { data }\end{array}$ & $\begin{array}{l}\text { Mengedit data } \\
\text { dan menyimpan } \\
\text { edit data } \\
\text { Menghapus data }\end{array}$ & Diterima \\
Diterima \\
$\begin{array}{l}\text { Pengujian hapus } \\
\text { data }\end{array}$ & & \\
\hline
\end{tabular}

\begin{tabular}{|c|c|c|c|}
\hline $\begin{array}{l}\mathrm{N} \\
\mathrm{o}\end{array}$ & Deskripsi & $\begin{array}{l}\text { Prosedur } \\
\text { Pengujian }\end{array}$ & Hasil \\
\hline 1 & $\begin{array}{l}\text { Pengujian } \\
\text { menampilkan } \\
\text { list tempat } \\
\text { ibadah }\end{array}$ & $\begin{array}{l}\text { Menampilkan } \\
\text { semua tempat } \\
\text { ibadah }\end{array}$ & Diterima \\
\hline 2 & $\begin{array}{l}\text { Pengujian } \\
\text { menampilkan } \\
\text { salah satu list } \\
\text { tempat ibadah }\end{array}$ & $\begin{array}{l}\text { Memilih salah } \\
\text { satu tempat } \\
\text { ibadah }\end{array}$ & Diterima \\
\hline 3 & $\begin{array}{l}\text { Pengujian } \\
\text { tempat ibadah } \\
\text { jarak terpendek }\end{array}$ & $\begin{array}{l}\text { Tekan salah satu } \\
\text { button tempat } \\
\text { ibadah }\end{array}$ & Diterima \\
\hline 4 & $\begin{array}{l}\text { Pengujian } \\
\text { menampilkan } \\
\text { peta lokasi }\end{array}$ & $\begin{array}{l}\text { Menekan icon } \\
\text { "Lokasi" }\end{array}$ & Diterima \\
\hline 5 & $\begin{array}{l}\text { Pengujian } \\
\text { menampilkan } \\
\text { jalur ke lokasi } \\
\text { tujuan }\end{array}$ & $\begin{array}{l}\text { Menekan icon } \\
\text { "Jalur" }\end{array}$ & Diterima \\
\hline
\end{tabular}

Tabel 6. Hasil lihat informasi

\begin{tabular}{cllc}
\hline No & Deskripsi & \multicolumn{1}{c}{$\begin{array}{c}\text { Prosedur } \\
\text { Pengujian }\end{array}$} & Hasil \\
\hline \multirow{2}{*}{1} & $\begin{array}{l}\text { Penujian Lihat } \\
\text { Detail } \\
\text { Informasi }\end{array}$ & $\begin{array}{l}\text { Menampilkan } \\
\text { detail informasi } \\
\text { tempat ibadah }\end{array}$ & Diterima \\
\hline
\end{tabular}

\section{Kesimpulan}

Penelitian rekayasa teknologi geolocation dengan metode djikstra berbasis android digunakan untuk menetukan jalur terpendek lokasi peribadatan di Kabupaten Kudus. Implementasi metode djikstra dalam pembuatan aplikasi pencarian lokasi dengan jalur terpendek juga telah terbukti berdasarkan perhitungan jarak dari posisi user berdiri dengan beberapa tempat peribadatan sekitar.

Hasil pengujian yang telah dilakukan menunjukkan, bahwa aplikasi telah berjalan sesuai dengan tujuan rekayasa teknologi geolocation berupa aplikasi pencarian lokasi peribadatan berbasis android, dan telah behasil dilakukan dengan jenis tempat peribadatannya meliputi masjid, gereja kristen, gereja katolik, dan vihara 


\section{Ucapan Terima Kasih}

Ucapan terima kasih kami sampaikan kepada DRPM Kementerian Riset dan Teknologi Pendidikan Tinggi yang telah memberikan dana untuk melakukan penelitian ini.

\section{Daftar Pustaka}

APJII (Asosiasi Penyelenggara Jasa Internet Indonesia), 2016. Penetrasi dan Perilaku Pengguna Internet Indonesia.

Anwar, S.N., Nugroho, I. Supriyanto, E., 2015. Model Rute Dan Peta Interaktif Posyandu Di Kota Semarang Menggunakan Geolocation Dan Haversine Berbasis Mobile Android. Proceeding SENDI_U, 2015.

Braun D., Sivils J., Shapiro A., Versteegh, J., 2001. Object Oriented Analysis and Design Team. Kennesaw State University CSIS 4650 -Spring.

Fajaruddin, N. Tarmuji, Ali., 2013. Geolocation Berdasarkan Gps Berbasis Mobile Web (Studi Kasus Pencarian Lokasi Hotel Di Yogyakarta), Jurnal Sarjana Teknik Informatika 1(1), 90-96.
Gusmão, A., Pramono, S.H. Sunaryo., 2013. Sistem Informasi Geografis Pariwisata Berbasis Web Dan Pencarian Jalur Terpendek Dengan Algoritma Dijkstra. Jurnal EECCIS 7(2), 125-30.

Munir, Rinaldi, 2005. Ilmu Komputer Matematika Diskrit. Edisi Ketiga. Informatika. Bandung

Sidi, M., Firdaus, R.F. Rahmadi, H., 2015. Pengujian Aplikasi Menggunakan BlackBox Testing Boundary Value Analysis. Jurnal Ilmiah Teknologi Informasi Terapan 1 (3), 31-36.

Pratiarso, A., Hadi, M.Z.S., Yuliana, M., Wahyuningdiyah, N., 2010. Perbandingan Metode Ant Colony Optimization. EEPIS: 129 38.

Roqib, A., Swasono, D.I., Retnani, W.E.Y., 2014. Sistem Informasi Geografis Pencarian Spbu Terdekat Dan Penentuan Jalur Terpendek Menggunakan Algoritma Dijkstra Di Kabupaten Jember Berbasis Web. Repository.unej.ac.id 1-7.

Yulianto, B., 2010. Teknologi Location Based Service (Global Positioning System) Pada Perangkat Mobile. ComTech 1 (1), 61-74. 